\title{
SPIE Defense, Security, and Sensing 2013 国際会議報告
}

片山 晴善（宇宙航空研究開発機構）

\section{1. はじめに}

2013/4/29〜5/3 にかけて開催された SPIE(国際光工学会) の Defense, Security, and Sensing (DSS) の開催結果につ いて報告する。SPIE DSS は防衛やセキュリティ関連のセン サを中心とした国際会議で，これまで例年カリフォルニア 州オーランドで開かれていたが，昨年からメリーランド州 ボルチモアにあるボルチモアコンベンションセンター(図 1) で開催されている。SPIE DSS 全体で 50 近いセッションが パラレルで開かれているが，本稿では筆者の関連する赤外 検出器関連のセッションである Infrared Technology and Applications XXXIX について報告する。

\section{Infrared Technology and Applications}

Infrared Technology and Applications は主に近赤外から 長波長赤外までの赤外線センサに関する研究発表が行われ ており，応用分野も防衛，民生，宇宙と多岐にわたること から非常に多くの出席者のあるセッションである。300 名 程度が収容できる会場が用意されており，特に初日は立ち見 が出るほどの盛況ぶりであった。発表件数はポスター発表 を含め 125 件の発表が行われた。発表の国別内訳を図 2 に 示す。赤外検出器は防衛用途が主であるため開発の進んで いるアメリカの発表が最も多くなるが，それ以外ではイス ラエル，フランス，トルコ，ドイツといった国からの発表 が多かった。日本からは 4 件の発表が行われた。

内容としては，検出器開発からその応用まで非常に多岐 にわたっており，応用分野も防衛，民生，宇宙からさまざま な事例が発表された。セッションは検出器別で分かれてお り，近赤外，短波長赤外域では InGaAs，さらに波長の長い 中波長赤外から長波長赤外域では InSb，HgCdTe，Type II 超格子, 量子井戸型, 量子ドット型, 非冷却型などさまざ まな検出器の研究成果が発表された。特に我々が近年開発 を進めている Type II 超格子関連の発表は 125 件中 17 件と， 全発表の約 $14 \%$ を占めており, 多岐にわたる赤外線検出器 関連の発表の中でも突出して多く, その関心の高さをうかが えた。InGaAs, InSb, HgCdTe といった検出器はすでに開発 の歴史も長く，方向性としてはより微細な画素ピッチ，大 きいフォーマットを目指した発表が多く聞かれた。HgCdTe では短波長領域で検出器を並べて配置することで最大 1600 万画素まで拡張できる天文用の検出器が発表された。

また近年量子型の検出器はその動作温度をより高温動作

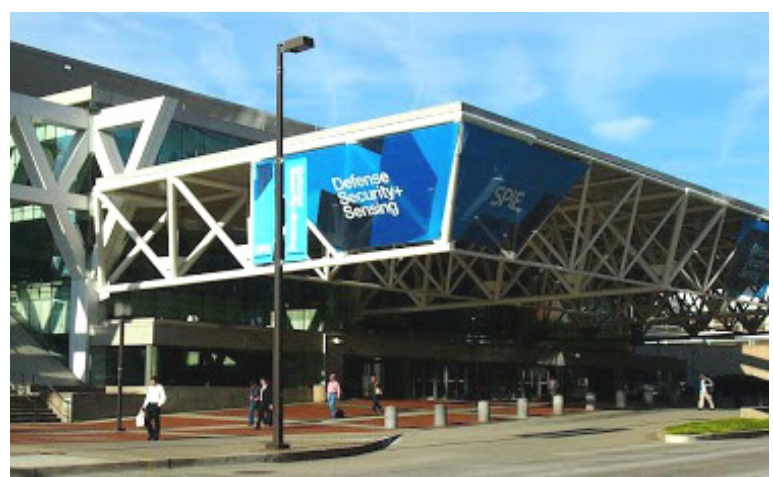

図 1 会場となったボルチモアコンベンションセンター

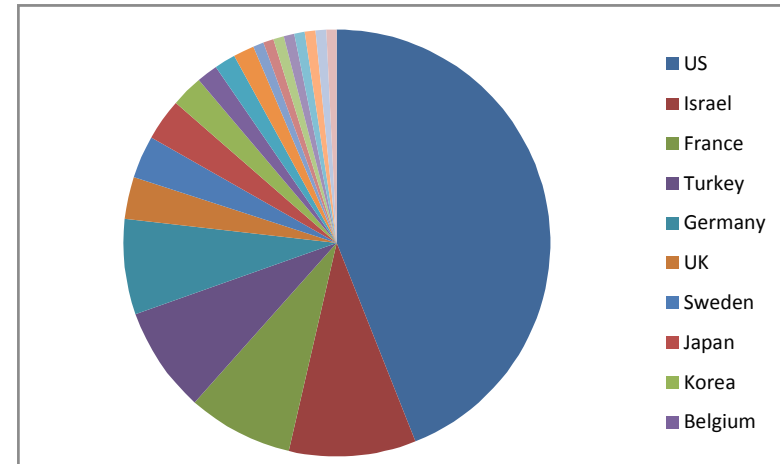

図 2 発表の国別内訳

とする High Operation Temperature (HOT) 検出器の開発 が進んでおり, 従来液体窒素温度（～ $77 \mathrm{~K})$ 付近の動作温 度であった中波長赤外域の検出器で $100 \mathrm{~K}$ 以上で動作する ものが発表されるなど, 徐々にリソースの大きい冷凍機か らペルチェ冷却への移行が視野に入りつつある。

日本からの発表は我々が行った Type II 超格子の発表以外 はすべて非冷却型の検出器に関するものであった。日本電 気からは市販の非冷却型では最小の画素ピッチとなる画素 ピッチ $12 \mu \mathrm{m}$ の検出器についての発表が行われた。三菱電 機からは熱吸収層にプラズモン構造を採用し, 波長選択性 を持たせる研究が発表された。また東芝からはダイオード 構造を採用した非冷却赤外検出器の発表が行われた。いず れの発表も海外からの関心は高く, 活発な議論が行われた。

非冷却型の検出器をはじめとする赤外線検出器に関して は国内でも関心は高いものの, 国際会議での発表はまだ少 なく，今後より多くの発表がなされることを期待したい。

(平成 25 年 7 月 4 日受付) 